ISSN 2072-6643

www.mdpi.com/journal/nutrients

Review

\title{
Human Folate Bioavailability
}

\section{Veronica E. Ohrvik ${ }^{1}$ and Cornelia M. Witthoft ${ }^{2, *}$}

1 Science Department, National Food Administration, P.O. Box 622, SE-75126 Uppsala, Sweden; E-Mail: Veronica.Ohrvik@slv.se

2 Department of Food Science, Swedish University of Agricultural Sciences, Uppsala BioCenter, P.O. Box 7051, SE-75007 Uppsala, Sweden

* Author to whom correspondence should be addressed; E-Mail: Cornelia.Witthoft@slu.se; Tel.: +46-18-67-1319; Fax: +46-18-67-2995.

Received: 2 March 2011; in revised form: 12 April 2011 / Accepted: 14 April 2011 /

Published: 18 April 2011

\begin{abstract}
The vitamin folate is recognized as beneficial health-wise in the prevention of neural tube defects, anemia, cardiovascular diseases, poor cognitive performance, and some forms of cancer. However, suboptimal dietary folate intake has been reported in a number of countries. Several national health authorities have therefore introduced mandatory food fortification with synthetic folic acid, which is considered a convenient fortificant, being cost-efficient in production, more stable than natural food folate, and superior in terms of bioavailability and bioefficacy. Other countries have decided against fortification due to the ambiguous role of synthetic folic acid regarding promotion of subclinical cancers and other adverse health effects. This paper reviews recent studies on folate bioavailability after intervention with folate from food. Our conclusions were that limited folate bioavailability data are available for vegetables, fruits, cereal products, and fortified foods, and that it is difficult to evaluate the bioavailability of food folate or whether intervention with food folate improves folate status. We recommend revising the classical approach of using folic acid as a reference dose for estimating the plasma kinetics and relative bioavailability of food folate.
\end{abstract}

Keywords: folate; folic acid; human bioavailability; intervention trials; post-dose plasma kinetics 


\section{Introduction}

The preventive effect of high folic acid intake against neural tube defects (NTD) is considered one of the most important nutritional discoveries in the period 1976-2006 [1]. Folate requirements are increased in life stages with amplified cell division, e.g., during pregnancy, as folate is essential during cellular replication. It is assumed that on a population level, nutritional requirements for folate, as with those for vitamin D, cannot be completely covered by a "varied diet", as recommended by national health authorities [2]. Dietary intake is below recommendations [3] in various Western societies owing to low consumption of folate-rich foods, e.g., pulses, citrus fruits, and leafy vegetables. It is estimated that an additional intake of 50-180 $\mu \mathrm{g}$ folate would allow most to reach the recommendations [4]. Populations of low socio-economic status have limited access to folate-rich foods, and furthermore natural food folates are rather unstable molecules, so that average losses in vitamin activity of around $30 \%$ can be expected during food processing [5]. However, the only risk factor for NTD which can be directly affected is inadequate dietary folate intake [6].

The chemically most stable folate form is synthetic folic acid [7], which is cheap to produce and therefore used for dietary supplements and food fortification. The introduction of folic acid-fortified staple foods has effectively decreased the prevalence of NTD, e.g., in the USA and Canada [8]. Significantly improved stroke mortality has also been reported [9]. In most countries, the Recommended Dietary Allowance (RDA) for folate is $300 \mu \mathrm{g} / \mathrm{day}$ for adults and $400 \mu \mathrm{g} / \mathrm{day}$ for women of childbearing age. With respect to vascular function, a folate intake according to the above recommendations has been shown to be beneficial, whereas higher doses do not provide any further health benefits [10]. The recommendations are more easily met by consumption of folic acid-fortified foods, owing to the higher stability and bioavailability of synthetic folic acid compared with native food folates [11]. The bioavailability of food folate is commonly estimated at $50 \%$ of folic acid bioavailability when establishing food recommendations $[2,12]$, but this should be considered a rough estimate, as data on the bioavailability of food folate vary between 30\% [13] and 98\% [14]. In the US, dietary recommendations are expressed in terms of Dietary Folate Equivalents (DFE) to account for differences in the bioavailability of native food folate and folic acid fortificant [12]. The discrepancies in folate bioavailability estimates are caused by the nature of the test food or meal (as thoroughly reviewed [15,16]), entrapping the vitamin and affecting stability and absorption, inter-subject variation, different study designs and, as recently suggested, metabolic inequities between different folate forms with respect to post-absorption plasma kinetics in the human metabolism [17-19]. Another important aspect is that the interpretation of bioavailability data is hampered by large methodological differences during folate quantification in clinical samples and test foods, which is complicated by lack of standardized reference methods for sample preparation and folate quantification, internal standards, and use of certified reference material [20-22]. Recent publications question the validity of the conventional approach used in bioavailability studies comparing folic acid with natural food folate [19], and demand approaches using whole diets rather than single foods [11] or data from meta-analyses of controlled feeding trials [23] in order to closer elucidate post-absorptive metabolism of the different folate forms. This is considered necessary for evaluating the adequacy of US RDA for folate [23], and also for estimating potential risks from mandatory folic acid fortification, as a high intake of synthetic folic acid is suggested to accelerate the development of, e.g., colorectal cancer [24-26]. 


\section{Synopsis of Post-Absorptive Folate Metabolism}

It is commonly assumed that food folates, which mainly exist in their polyglutamyl form, are absorbed in the jejunum as monoglutamyl folates after removal of the polyglutamyl chain by intestinal $\gamma$-glutamyl hydrolase [27], and thereafter reduced and methylated in the enterocyte. Passive diffusion across the cell membrane is limited [28], and occurs only at high doses. To a minor extent folate is also absorbed in the colon; and it is suggested that colonic absorption may contribute significantly to total folate absorption [29], but it is unknown how relevant this is for maintaining folate status. However, it has been shown for humans [29,30] and pigs [31] that folates synthesized by colon bacteria are bioavailable. Absorbed folate is transported to the liver, which contains about half the body pool of folate [32,33] and retains 10-20\% of absorbed folate due to the first-pass effect [15], while the rest is transported via the systemic circulation to body tissues. Some liver folate participates in the enterohepatic circulation and is secreted into bile [33,34]. However, most biliary folate is reabsorbed, supposedly to moderate between-meal fluctuations in folate supply to cells [34].

In the cell nucleus, tetrahydrofolate-polyglutamate $\left(\mathrm{H}_{4}\right.$-folate $)$ is the substrate for both nucleotide synthesis and the methylation cycle (Figure 1), by providing or accepting one-carbon atoms [35]. 5-methyltetrahydrofolate (5- $\mathrm{CH}_{3}-\mathrm{H}_{4}$ folate) donates a methyl group to vitamin $\mathrm{B} 12$, which transfers it to homocysteine, avoiding accumulation of homocysteine in the cell and maintaining synthesis of amino acids. The first signs of deficiency appear in tissues with rapid cell turnover and during life stages with increased cell division, such as pregnancy or growth [36], and can result in megaloblastic anemia by impaired synthesis of red blood cells [33].

Figure 1. Role of folate in nucleotide synthesis and the methylation cycle (adapted from [37]). Enzymes are shaded and their end-products marked with boxes. Adapted from [38], p. 19.

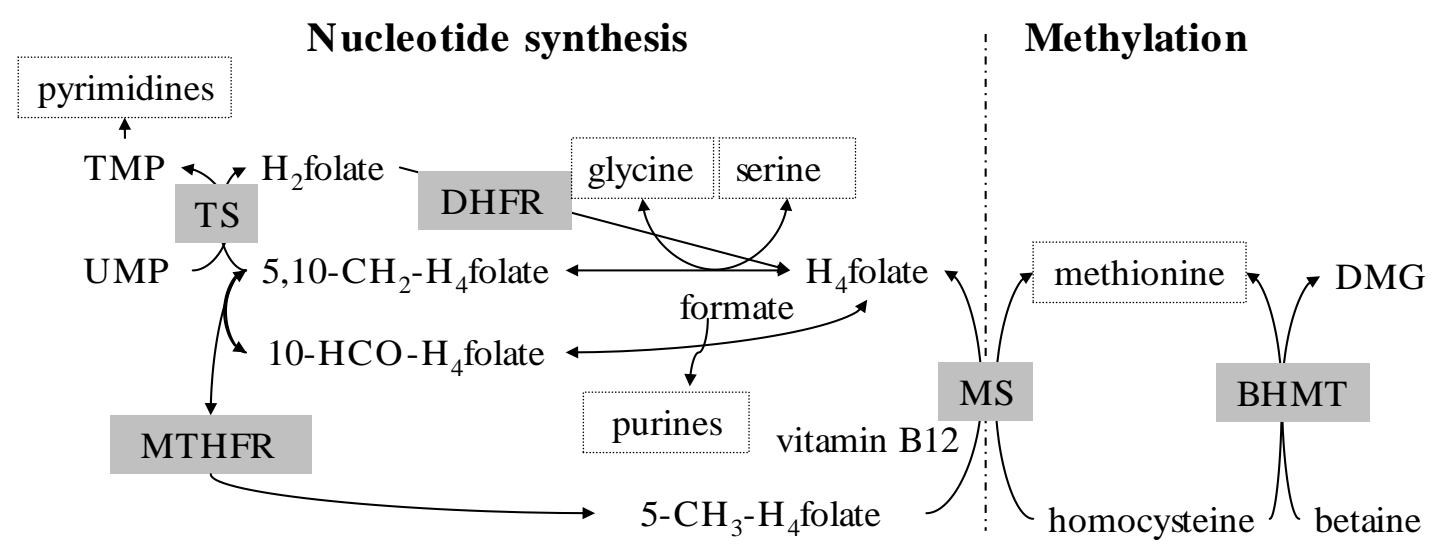

BHMT: betaine-homocysteine methyltransferase; DHFR: dihydrofolate reductase; DMG: dimethylglycine; MS: methionine synthase; MTHFR: methylenetetrahydrofolate reductase; TMP: thymidine monophosphate; TS: thymidylate synthase; UMP: uridine monophosphate.

It is estimated that about $0.3-0.8 \%$ of the folate pool is excreted daily, mainly in the form of catabolites not affected by intake [32,39]. Renal excretion of intact folate is as low as $\sim 5 \%$ after physiological doses [34,40-42], but it increases at higher folate intake [37]. In human feces, about $400 \mathrm{nmol} /$ day folate can be found, originating mainly from bacterial production, lysed enterocytes, and 
gastrointestinal secretions (e.g., bile) [34,43]. Little to at most $20 \%$ of fecal folate is estimated to derive from non-absorbed food folate [34,44-47].

Genetic polymorphisms of key enzymes and carriers can affect cellular folate metabolism and result in decreased enzyme activity, increased folate requirements [48-50], and an increased risk of NTD [51]. Furthermore, vitamin B12 deficiency reduces the activity of methionine synthase (MS; Figure 1), resulting in cellular accumulation of homocysteine and 5-methyltetrahydrofolate according to the methyl trap theory [37].

\section{Estimation of Folate Bioavailability—Still a Challenge}

Accurate estimation of dietary folate bioavailability is a prerequisite for the formulation of nutrition recommendations, but is still a challenge. Folate absorption is defined as the in vivo process by which folate proceeds from the site of administration to the site of measurement (usually plasma) [52]. Folate bioavailability is defined as the fraction of ingested folate that is absorbed and can be used for metabolic processes [16]. Findings from early bioavailability studies until the mid-1990s discussed by others indicate the need for further investigations on folate bioavailability and influencing factors [53].

Long-term (Tables 1 and 2) and short-term (Table 3) human trials, conducted during the past 15 years, have produced inconclusive findings regarding dietary folate bioavailability, complicating the interpretation of data by different definitions for the term bioavailability and differing study designs. Furthermore, difficulties with respect to the exact quantification of ingested folate dose from food samples and in clinical samples limit the validity of many studies [19,54]. Although there are recommendations for the extraction of food samples using trienzyme treatment [55-57], this approach is used in only some studies [13,14,45,58-64]. Others apply dienzyme [46] or monoenzyme $[18,40,42,65]$ extraction prior to folate quantification by microbiological assay or HPLC (LC-MS or LC-FLD). Information is sometimes missing $[17,66,67]$, or dietary folate doses are determined by calculation [19,68-70] (Tables 1-3).

Table 1. Dietary folate intervention trials resulting in no significant effects (presented as change (\%) compared with baseline) on folate status.

\begin{tabular}{|c|c|c|c|c|c|c|c|c|c|c|c|c|}
\hline \multirow[b]{2}{*}{$\begin{array}{c}\text { Intervention } \\
\text { diet }\end{array}$} & \multicolumn{2}{|c|}{ Folate intake } & \multirow[t]{2}{*}{$\mathbf{W}$} & \multirow[t]{2}{*}{$N$} & \multirow[t]{2}{*}{ Age } & \multicolumn{2}{|c|}{ Erythrocyte folate } & \multicolumn{2}{|c|}{ p/s-folate } & \multicolumn{2}{|c|}{ tHcy $(\mu \mathrm{mol} / \mathrm{L})$} & \multirow[b]{2}{*}{ Ref. } \\
\hline & $\begin{array}{c}\text { Dose }(\mu \mathrm{g} / \mathrm{day}) \\
(\mathbf{Q})^{1}\end{array}$ & $\begin{array}{c}\text { Total }^{2} \\
(\mu \mathrm{g} / \mathrm{day})\end{array}$ & & & & $\begin{array}{l}\text { Baseline } \\
(\mathrm{nmol} / \mathrm{L})\end{array}$ & $\begin{array}{l}\text { End } \\
(\%) \\
\end{array}$ & $\begin{array}{l}\text { Baseline } \\
(\mathrm{nmol} / \mathrm{L})\end{array}$ & $\begin{array}{l}\text { End } \\
(\%)\end{array}$ & $\begin{array}{l}\text { Baseline } \\
(\mathrm{nmol} / \mathrm{L}) \\
\end{array}$ & $\begin{array}{l}\text { End } \\
(\%)\end{array}$ & \\
\hline Control & $2(\mathrm{C})^{1}$ & & 4 & $35, \mathrm{~F}$ & $41 \pm 3^{3}$ & & & $15 \pm 9^{3}$ & -15 & $11 \pm 4^{3}$ & -10 & {$[68]$} \\
\hline 5-a-day fruit/veg & $43(\mathrm{C})^{1}$ & & 4 & $36, \mathrm{~F}$ & $42 \pm 4^{3}$ & & & $17 \pm 9^{3}$ & -6 & $10 \pm 3^{3}$ & 0 & \\
\hline Control & $0(\mathrm{~T})^{1}$ & 186 & 4 & $18, \mathrm{M}$ & $23-39^{4}$ & & & $16 \pm 9^{3}$ & -7 & $12 \pm 4^{3}$ & 0 & [13] \\
\hline Spinach & $200(\mathrm{~T})^{1}$ & 384 & 4 & $18, \mathrm{M}$ & $23-39^{4}$ & & & $14 \pm 5^{3}$ & -7 & $12 \pm 3^{3}$ & 0 & \\
\hline Yeast & $200(\mathrm{~T})^{1}$ & 411 & 4 & $19, \mathrm{M}$ & $23-39^{4}$ & & & $15 \pm 7^{3}$ & -17 & $12 \pm 3^{3}$ & -9 & \\
\hline Control & $23(\mathrm{~L})^{1}$ & 210 & 12 & $9, \mathrm{~F}$ & $17-40^{4}$ & $709 \pm 157^{3,5}$ & $+3^{5}$ & & & & & [66] \\
\hline High folate diet & $201(\mathrm{~L})^{1}$ & 410 & 12 & $10, \mathrm{~F}$ & $17-40^{4}$ & $797 \pm 200^{3,5}$ & $+7^{5}$ & & & & & \\
\hline
\end{tabular}

F: females; M: males; W: weeks; $N$ : number of subjects; Veg: vegetables; p/s-folate: plasma/serum folate concentration; tHcy: total homocysteine concentration in plasma/serum; End $(\%)$ : relative increase $(+)$ or decrease $(-)$ in status parameter at end of intervention compared with baseline. ${ }^{1} \mathrm{Q}$ : Quantification of folate content in intervention doses by (C: calculation, T: using trienzyme extraction, L: lacking information); ${ }^{2}$ Estimated by dietary recall (either reported as total folate intake or estimated as dose + folate intake at screening);

${ }^{3}$ Mean $\pm \mathrm{SD} ;{ }^{4}$ Age reported as inclusion criteria; ${ }^{5}$ Erythrocyte folate concentrations given in $\mu \mathrm{g} / \mathrm{L}, \mathrm{calculated}$ to $\mathrm{nmol} / \mathrm{L}\left(0.4600^{-1} \mathrm{nmol} / \mu \mathrm{g}\right)$. 
Table 2. Dietary folate intervention trials resulting in significant effects (presented as change (\%) compared with baseline) on folate status.

\begin{tabular}{|c|c|c|c|c|c|c|c|c|c|c|c|c|}
\hline \multirow{2}{*}{ Intervention diet } & \multicolumn{2}{|c|}{ Folate intake $(\mu \mathrm{g} /$ day $)$} & \multirow[t]{2}{*}{ W } & \multirow[t]{2}{*}{$N^{2}$} & \multirow[t]{2}{*}{ Age } & \multicolumn{2}{|c|}{ Erythrocyte folate } & \multicolumn{2}{|c|}{ p/s-folate } & \multicolumn{2}{|l|}{ tHcy } & \multirow{2}{*}{ Ref. } \\
\hline & Dose $(Q)^{1}$ & Total & & & & Baseline (nmol/L) & End $(\%)$ & Baseline (nmol/L) & End $(\%)$ & Baseline $(\mu \mathrm{mol} / \mathrm{L})$ & End $(\%)$ & \\
\hline Control & 0 & 236 & 16 & 43 & - & & & $26 \pm 8^{3}$ & -4 & $9 \pm 3^{3}$ & 0 & [69] \\
\hline 5-a-day fruit/vegetables & $63(\mathrm{C})$ & 306 & 16 & 41 & - & & & $26 \pm 7^{3}$ & $+7^{\bullet}$ & $10 \pm 4^{3}$ & -11 & \\
\hline Low folate diet & $0(\mathrm{~L})$ & 131 & 4 & 23 & $50 \pm 4^{3}$ & & & $13 \pm 6^{3}$ & -8 & $14 \pm 6^{3}$ & -8 & [67] \\
\hline $500 \mathrm{~g}$ fruit and vegetables & $97(\mathrm{~L})$ & 228 & 4 & 24 & $49 \pm 6^{3}$ & & & $16 \pm 10^{3}$ & $0^{\bullet}$ & $12 \pm 4^{3}$ & $-9^{*}$ & \\
\hline Control & 0 & 239 & 12 & $17, \mathrm{~F}$ & $48(38,57)^{7}$ & $900(647,1079)^{7}$ & $-22^{7}$ & $12(11,15)$ & $0^{7}$ & $9(7,11)$ & $+10^{7}$ & [59] \\
\hline 5 slices bread & $70(\mathrm{~T})$ & 379 & 12 & $17, \mathrm{~F}$ & $47(40,55)^{7}$ & $855(635,992)^{7}$ & -18 & $12(9-16)$ & 0 & $9(8,11)$ & $-21 *$ & \\
\hline Breakfast (SNO [71]) & $125(\mathrm{~T})$ & 437 & 12 & $17, \mathrm{~F}$ & $49(35,53)^{7}$ & $805(742,909)^{7}$ & $+12^{\bullet}$ & $12(10,16)$ & +8 & $7(7,9)$ & $-23 *$ & \\
\hline Folic acid-fortified bread & $188(\mathrm{~T})$ & 461 & 4 & 31 & $36 \pm 13^{3}$ & $606 \pm 224^{3}$ & $+13 *$ & $12 \pm 5^{3}$ & $+25 *$ & & & [60] \\
\hline Rye and orange juice & $184(\mathrm{~T})$ & 461 & 4 & 33 & $36 \pm 13^{3}$ & $561 \pm 190^{3}$ & $+15^{*}$ & $10 \pm 3^{3}$ & $+23 *$ & & & \\
\hline Folic acid & $150(\mathrm{~T})$ & $221^{4}$ & 4 & 15 & $19-48^{5}$ & & & $12 \pm 4^{3}$ & +20 & $10 \pm 2^{3}$ & -11 & [61] \\
\hline Vegetables, fruits, liver pate & $331(\mathrm{~T})$ & $427^{4}$ & 4 & 29 & $19-41^{5}$ & & & $12 \pm 4^{3}$ & $+33^{\star}$ & $10 \pm 3^{3}$ & -11 & \\
\hline Placebo & 0 & $\sim 360^{9}$ & 16 & 43 & $46 \pm 2$ & $895 \pm 60$ & +3 & $26 \pm 2$ & -1 & $9 \pm 0.4$ & 0 & [19] \\
\hline Food group & $200(C)$ & $\sim 305^{9}$ & 16 & 38 & $45 \pm 2$ & $872 \pm 61$ & $+14^{\star}$ & $25 \pm 2$ & $+19^{\star}$ & $10 \pm 1$ & $-6^{\star}$ & \\
\hline 5-methyltetrahydrofolate caps & $200(\mathrm{P})$ & $\sim 295^{9}$ & 16 & 42 & $45 \pm 2$ & $793 \pm 42$ & $+30^{\bullet}$ & $22 \pm 2$ & $+41^{\bullet}$ & $10 \pm 1$ & -14 & \\
\hline Folic acid caps & $200(\mathrm{P})$ & $\sim 325^{9}$ & 16 & 40 & $48 \pm 2$ & $833 \pm 56$ & $+28^{\star}$ & $24 \pm 2$ & $+44^{\star}$ & $9 \pm 0.4$ & $-15^{\star}$ & \\
\hline Control & 0 & $210^{4}$ & 4 & 22 & $23 \pm 8^{3}$ & $347 \pm 79^{3}$ & -1 & $13 \pm 3^{3}$ & 0 & $10 \pm 3^{3}$ & +9 & {$[14]$} \\
\hline Fruit and vegetables & $350(\mathrm{~T})$ & $560^{4}$ & 4 & 23 & $23 \pm 8^{3}$ & $338 \pm 81^{3}$ & $+16^{\star}$ & $14 \pm 3^{3}$ & $+30^{\star}$ & $11 \pm 5^{3}$ & $-10^{\star}$ & \\
\hline Control & $0(\mathrm{~T})$ & 242 & 4 & 14 & $60 \pm 15^{3}$ & & & $18(15-22)^{6}$ & $0^{6}$ & $14(12-16)^{6}$ & $0^{6}$ & [62] \\
\hline High folate diet & $355(\mathrm{~T})$ & 618 & 4 & 20 & $58 \pm 18^{3}$ & & & $18(16-19)^{6}$ & $28^{6}$ & $12(11-13)^{6}$ & $-9^{6,}$ & \\
\hline Control & $0(\mathrm{~T})$ & 227 & 12 & 15 & $36-71^{8}$ & $539 \pm 166^{3}$ & 0 & $15(12-18)^{6}$ & $-7^{6}$ & $12(11-14)^{6}$ & $0^{6}$ & {$[58]$} \\
\hline High folate diet & $\sim 350(\mathrm{~T})$ & 707 & 12 & 15 & $36-71^{8}$ & $571 \pm 162^{3}$ & +11 & $15(13-17)^{6}$ & $+32^{6,}$ & $11(9-12)^{6}$ & $-10^{6}$ & \\
\hline Pericarp flour bread & $223(\mathrm{~T})$ & 436 & 16 & 25 & $48-56^{5}$ & $497(414-581)^{6}$ & $+14^{6}$ & $13(11-15)^{6}$ & $+7^{6}$ & $10(8-11)^{6}$ & $-25^{6}$ & [63] \\
\hline Aleurone flour bread & $615(T)$ & 836 & 16 & 25 & $46-54^{5}$ & $509(434-584)^{6}$ & $+34^{6,}$ & $13(10-16)^{6}$ & $+52^{6}$ & $9(8-10)^{6}$ & $-29^{6,}$ & \\
\hline
\end{tabular}

W: week; caps: capsules; $N$ : number of subjects; F: females; p/s-folate: plasma/serum folate concentration; tHcy: total homocysteine concentration in plasma/serum. End (\%): relative increase (+) or decrease (-) in status parameter at end of intervention compared with baseline. ${ }^{1}$ Q: Quantification of folate content in intervention doses by (C: calculation, T: using trienzyme extraction, L: lacking information); P: as provided by manufacturer; ${ }^{2}$ Females and males; ${ }^{3}$ Mean $\pm \mathrm{SD} ;{ }^{4}$ Folate dose analyzed and not estimated by dietary recall; ${ }^{5}$ Range; ${ }^{6}$ Geometric means (95\% CI); ${ }^{7}$ Median (quartile 1 , quartile 3 ); ${ }^{8}$ Age reported as inclusion criteria; ${ }^{9}$ Folate intake given in nmol, calculated to $\mu \mathrm{g}\left(0.460^{-1} \mathrm{nmol} / \mu \mathrm{g}\right) . *$ Significant effect within the group compared with baseline $(P<0.05) ;{ }^{\bullet}$ Significant effect compared with control $(P<0.05)$. 
Table 3. Trials using plasma concentration to assess the bioavailability of food folates or fortificants.

\begin{tabular}{|c|c|c|c|c|c|c|}
\hline & $\begin{array}{c}\text { Dose } \\
\text { nmol }^{1}\end{array}$ & $\begin{array}{c}\text { AUC or App } \\
\text { Abs }^{2} \\
\end{array}$ & $\begin{array}{c}\text { Sampling duration } \\
(\mathrm{nr} / \mathbf{4} \mathrm{h})^{3}\end{array}$ & $\begin{array}{l}\text { Females } \\
+ \text { males } \\
\end{array}$ & Age $^{4}$ & Ref. \\
\hline \multicolumn{7}{|c|}{ Size of AUC $(h \cdot n m o l / L)$ from supplements and fortified foods } \\
\hline$\left[{ }^{13} \mathrm{C}_{6}\right]$-folic acid & 634 & 19 & $8 \mathrm{~h}(8)$ & $10^{10}$ & $31 \pm 1$ & [17] \\
\hline Folic acid $^{5}$ & 1134 & 146 & $10 \mathrm{~h}(6)$ & $0+13$ & $26 \pm 6$ & [64] \\
\hline Folic acid & 1134 & 40 & $10 \mathrm{~h}(6)$ & $6+6$ & $36-69$ & [45] \\
\hline Folic acid & 1193 & $37,49^{7}$ & $7 \mathrm{~h}(3)$ & $8+8$ & $20-50$ & [65] \\
\hline Folic acid & 907 & 62 & $10 \mathrm{~h}(4)$ & $10+10$ & $27 \pm 3$ & [70] \\
\hline$\left[{ }^{13} \mathrm{C}_{5}\right]$-folic acid in bread & $450(\mathrm{D})$ & 28 & $12 \mathrm{~h}(7)$ & $5+3$ & $39-66$ & [46] \\
\hline$\left[{ }^{13} \mathrm{C}_{5}\right]$-folic acid in breakfast meal & 450 (D) & 26 & $12 \mathrm{~h}(7)$ & $5+3$ & $39-66$ & [46] \\
\hline$(6 S)-\left[{ }^{13} \mathrm{C}_{6}\right]-5-\mathrm{HCO}-\mathrm{H}_{4}$ folate & 500 & 42 & $8 \mathrm{~h}(8)$ & $10^{10}$ & $31 \pm 1$ & [17] \\
\hline$(6 S)-5-\mathrm{CH}_{3}-\mathrm{H}_{4}$ folate ${ }^{5}$ & 1088 & 142 & $10 \mathrm{~h}(6)$ & $0+13$ & $26 \pm 6$ & [64] \\
\hline$(6 S)-5-\mathrm{CH}_{3}-\mathrm{H}_{4}$ folate ${ }^{5}$ & $830^{6}$ & $44,88^{6}$ & $10 \mathrm{~h}(7)$ & $0+2$ & 55,77 & [40] \\
\hline$(6 S)-5-\mathrm{CH}_{3}-\mathrm{H}_{4}$ folate i.m. ${ }^{5}$ & $830^{6}$ & $111,144^{6}$ & $10 \mathrm{~h} \mathrm{(7)}$ & $0+2$ & 55,77 & [40] \\
\hline$(6 S)-\left[{ }^{13} \mathrm{C}_{5}\right]-5-\mathrm{CH}_{3}-\mathrm{H}_{4}$ folate in bread & 450 (D) & 66 & $12 \mathrm{~h}(7)$ & $5+3$ & $39-66$ & [46] \\
\hline \multicolumn{7}{|c|}{ Size of AUC $(h \cdot n m o l / L)$ from native food folates } \\
\hline Broccoli $^{5}$ & $440(\mathrm{M})$ & $27,41^{6}$ & $10 \mathrm{~h}(7)$ & $0+2$ & 55,77 & [40] \\
\hline Strawberries ${ }^{5}$ & $450(\mathrm{M})$ & $32,41^{6}$ & $10 \mathrm{~h}(7)$ & $0+2$ & 55,77 & [40] \\
\hline Spinach, monoglutamate ${ }^{8}$ & $820(\mathrm{~T})$ & 31 & $10 \mathrm{~h}(6)$ & $6+6$ & $36-69$ & [45] \\
\hline Spinach, polyglutamate $^{9}$ & $990(\mathrm{~T})$ & 27 & $10 \mathrm{~h}(6)$ & $6+6$ & $36-69$ & [45] \\
\hline \multirow[t]{2}{*}{ Spinach } & $544(\mathrm{C})$ & 41 & $10 \mathrm{~h}(4)$ & $10+10$ & $27 \pm 3$ & [70] \\
\hline & $1088(\mathrm{C})$ & 71 & & & & \\
\hline Aleurone flour & $1167(\mathrm{M})$ & $46,38^{7}$ & $7 \mathrm{~h}(3)$ & $8+8$ & $20-50$ & [65] \\
\hline Wheat bran & $213(\mathrm{M})$ & $8,6^{7}$ & $7 \mathrm{~h}(3)$ & $8+8$ & $20-50$ & [65] \\
\hline \multicolumn{7}{|c|}{ Apparent absorption (\%) from supplements, fortified foods and food folate } \\
\hline$\left[{ }^{13} \mathrm{C}_{6}\right]$-folic acid & 634 & $24 \%$ & $8 \mathrm{~h}(8)$ & $14^{10}$ & $33 \pm 2$ & [18] \\
\hline$(6 S)-\left[{ }^{13} \mathrm{C}_{6}\right]-5-\mathrm{HCO}-\mathrm{H}_{4}$ folate & 500 & $38 \%$ & $8 \mathrm{~h}(8)$ & $14^{10}$ & $33 \pm 2$ & [18] \\
\hline Spinach $\left[{ }^{15} \mathrm{~N}_{1-7}\right]$ folate & $588(\mathrm{M})$ & $44 \%$ & $8 \mathrm{~h}(8)$ & $14^{10}$ & $33 \pm 2$ & [18] \\
\hline Folic acid in bread ${ }^{5}$ & $491^{6}(\mathrm{M})$ & $74 \%$ & $10 \mathrm{~h}(7)$ & $1+8$ & $51-79$ & [44] \\
\hline$(6 S)-5-\mathrm{CH}_{3}-\mathrm{H}_{4}$ folate in fermented milk ${ }^{5}$ & $450^{6}(\mathrm{M})$ & $86 \%$ & $10 \mathrm{~h} \mathrm{(7)}$ & $1+8$ & $51-79$ & [44] \\
\hline Yeast folate $^{5}$ & $155^{6}(\mathrm{M})$ & $80 \%$ & $10 \mathrm{~h}(7)$ & $1+8$ & $51-79$ & [44] \\
\hline
\end{tabular}

5-HCO- $\mathrm{H}_{4}$ folate: 5-formyltetrahydrofolate; 5- $\mathrm{CH}_{3}-\mathrm{H}_{4}$ folate: 5-methyltetrahydrofolate; $\left[{ }^{13} \mathrm{C}_{5}\right]-,\left[{ }^{13} \mathrm{C}_{6}\right]-:$ stable isotope-labeled $\left(5\right.$ or $6{ }^{13} \mathrm{C}$ ); $(6 S)$-: bioactive folate diastereoisomer; ${ }^{1}$ Folate content in food intervention doses quantified by (T: trienzyme, D: dienzyme or M: Monoenzyme extraction, or by C: calculation); ${ }^{2}$ App abs: apparent absorption, estimated by (kinetic modeling [18,42] or AUC: area under the curve (Mean or Median)); ${ }^{3}$ Number of sampling occasions during $0-4 \mathrm{~h}$ post-dose in brackets; ${ }^{4}$ Mean \pm SD or range; ${ }^{5}$ Presaturation with $\sim 1 \mathrm{mg}$ [38,42] or $5 \mathrm{mg}$ [72] folic acid/day from day -9 to day -2 prior to each test day; ${ }^{6}$ Conversion factors from $\mu \mathrm{g}$ to nmol: $0.441^{-1} \mathrm{nmol} / \mu \mathrm{g}$ (folic acid) and $0.460^{-1} \mathrm{nmol} / \mu \mathrm{g}$ (plasma folate and 5-methyltetrahydrofolate) ${ }^{7}$ Females and males reported separately; ${ }^{8}$ Folate monoglutamates from enzymatic cleavage of endogenous spinach folates after cell disruption; ${ }^{9}$ Native spinach folate polyglutamates; ${ }^{10}$ No data on gender.

\subsection{Intervention Trials}

Physiological effects of dietary folate interventions are commonly studied in 4-6 week trials assessing changes in one or several folate status parameters, e.g., fasting serum folate, erythrocyte folate, and plasma total homocysteine (Tables 1 and 2). 
It seems appropriate to assess more than one status parameter, since the sensitivity of parameters and the rapidity of response varies. For example, a 4-week intervention study found the estimated bioavailability of food folate compared with folic acid to be $78 \%$ based on serum folate concentrations, $98 \%$ based on erythrocyte folate concentrations, and only $60 \%$ based on homocysteine concentrations [14]. It is recommended that the appropriateness of the chosen status parameters in intervention trials be evaluated based on reliability coefficients [73-75]. Reliability coefficients show the ratio of between-subject variability to total variability, including the variability of the analytical method. Reliability coefficients for the common response parameters in folate intervention studies are within the range $0.65-0.97$ [38,73-75].

Interpretation of the effects of intervention on folate status and bioavailability is further complicated due to the fact that several genetic polymorphisms of folate/homocysteine metabolic enzymes may affect the individual parameters differently $[72,76]$.

Several intervention trials report a low relative bioavailability of food folates compared with folic acid (Tables 1 and 2) $[13,58,66]$. On the other hand, improvement of folate status parameters from food folates has been observed compared with a control group receiving no additional folate (Table 2) [59,67].

Data from a very recent study [19] show that the relative response of folate status parameters after food intervention differs compared with a reference group receiving supplemental folic acid or the bioactive diastereoisomer $(6 S)$-5-methyltetrahydrofolate $\left(\right.$ Metafolin ${ }^{\circledR}$ ). As the intervention with folic acid results in a greater increase in fasting plasma folate concentrations than bioactive folate diastereoisomer, the estimated relative bioavailability of food folate is lower when compared with the supplemental folic acid receiving control group. Those authors therefore recommend avoiding using folic acid as the reference dose in long-term studies. However, this hypothesis remains to be confirmed, as some intervention trials with foods have resulted in similar improvements of folate status compared with equimolar or smaller doses of folic acid from fortified foods or supplements $[60,61,63]$.

\subsection{Short-Term Trials}

Short-term absorption or bioavailability of food folate has been found to be incomplete compared with that of folic acid [77], and as a result a number of approaches for assessment are now used.

The plasma area under the curve (AUC) approach is based on the assumption that with standardized study design, the post-dose plasma folate concentrations over time correspond to the folate fraction absorbed from a single dose. Relative folate absorption is commonly assessed, comparing the test dose with an oral reference dose of supplemental folate, often folic acid (Table 3). Comparisons of the relative AUC after a single dose of supplemental folic acid and reduced folates show that the trials using presaturation of volunteer's body stores [40,44,64] result in greater AUCs than others. This suggests that after administration of an oral dose, the amount of folate in peripheral plasma is affected by the hepatic first-pass effect and volunteer's body stores, which could explain the variable results in published bioavailability data. The data are too few to systematically evaluate whether equimolar doses of folic acid and reduced folate result in differently sized plasma AUCs, as administered doses, sampling intervals, number of sampling occasions, and presaturation of volunteers vary between trials (Table 3). 
In three previous trials $[18,45,70]$, the AUC or apparent absorption of spinach folate was estimated to be similar or greater than almost equimolar doses of synthetic folic acid, demonstrating in theory similar bioavailability. However, it was hypothesized that reduced folates and folic acid show differing plasma and distribution kinetics [17,18]. It was suggested that the initial site of folic acid metabolism is not the enterocyte, as accepted in the past, but the liver cell, and liver enzymes are postulated to have a greater affinity for oxidized folic acid than reduced folates. Therefore it is not considered appropriate to compare natural folate test doses (e.g., 5-methyltetrahydrofolate, 5-formyltetrahydrofolate) with a folic acid reference dose [18].

With the aim of estimating absolute folate absorption and avoiding complications from differing plasma kinetics from test and reference compounds, a reference dose of the bioactive diastereoisomer (6S)-5-methyltetrahydrofolate, administered by intramuscular injection to bypass the liver, was used to estimate the bioavailability of native folate from foods [40]. In this pilot trial with only two volunteers, the AUCs from intramuscularly administered (6S)-5-methyltetrahydrofolate were greater than those from an oral dose of the same compound (Table 3), indicating partial hepatic retention of the orally administered folate dose even when volunteers were presaturated.

In some trials the apparent absorption accounting for the folate distribution volume in the body has been determined using biokinetic modeling, and these estimated that $24-86 \%$ of supplemental or native food folate is absorbed (Table 3) [18,44]. Some studies [78] are limited by too short post-dose plasma sampling, so that the AUC cannot be estimated and extrapolated for exact assessment of absorbed folate, or no plasma AUC data are provided [42,79].

The determination of folate bioavailability by urinary folate excretion ratio is based on the hypothesis that urinary excretion of $\left[{ }^{13} \mathrm{C}\right]$-labeled folate from an oral dose corresponds to that of a differently labeled reference dose of $\left[{ }^{2} \mathrm{H}\right]$-folic acid from analogous intravenous administration. This dual-label stable isotope protocol, when used to determine relative folate bioavailability of food folates and added fortificants, produces values of 37-153\% [41,42,80-82]. However, these studies also generated the information that reduced folates and folic acid are handled differently by the body; and (6S)-5-methyltetrahydrofolate was recommended as the reference dose [80].

Studies using the oral-fecal balance technique for folate are commonly carried out using ileostomy subjects, who do not possess a colon microflora affecting fecal folate content, in combination with the AUC technique. Absorbed folate is inversely correlated to folate content in stomal effluent. However, not all folate, found in ileostomy effluent or feces, originates from non-absorbed orally ingested folate [43], and therefore baseline folate excretion has to be assessed. Baseline folate excretion is determined either on a folate-free study day using a standardized protocol [40,44], or after a known reference dose of synthetic folic acid [45]. The use of stable isotope labeling allows folate from the dose to be distinguished from endogenous folate [34,83]. Folate bioavailability from foods and a meal has been estimated to be 50-90\% using the balance technique [30,44-46,84].

A common criticism of short-term protocols is the use of non-physiological doses, or large portions of test foods that are not likely to be consumed in a meal by the general population, e.g., $30 \mathrm{~g}$ of yeast [77] or $500 \mathrm{~g}$ of spinach [70], to overcome insufficient sensitivity of the model. To improve sensitivity and minimize or standardize hepatic retention of absorbed folate at first passage, folate body stores can be presaturated with supplemental folic acid [77] (Table 3). However, this approach can also 
be questioned, as it has been shown in vitro that high exposure to folic acid reduces cellular uptake into Caco-2 and kidney cells by down-regulation of genes coding for folate absorption and transport [85].

A recent study uses a combined approach of various short-term techniques in the form of a stable isotope AUC and ileostomy model $[46,47]$ to determine acute absorption of equimolar doses of either stable isotope-labeled $(6 S)-\left[{ }^{13} \mathrm{C}_{5}\right] 5$-methyltetrahydrofolate or $\left[{ }^{13} \mathrm{C}_{5}\right]$ folic acid from bread or a breakfast meal (Table 3). The plasma AUC of labeled folate after ingestion of the bread fortified with bioactive $(6 S)-\left[{ }^{13} \mathrm{C}_{5}\right] 5$-methyltetrahydrofolate was twice that for food labeled with folic acid, whereas the excretion of labeled folate into ileostomy effluent did not differ significantly and was as low as $10 \%$ of the dose, indicating high bioavailability providing that no severe oxidative degradation of non-absorbed labeled folate occurred in frequently sampled ileostomy effluent. For supplemental $(6 S)-\left[{ }^{13} \mathrm{C}_{5}\right] 5$-methyltetrahydrofolate too, a greater median plasma AUC was observed compared with $\left[{ }^{13} \mathrm{C}_{5}\right]$ folic acid [86] (Figure 2).

These findings confirm the hypothesis of different metabolic handling of reduced folates and folic acid in the human body. The consequence is a recommendation to revise the classical approach of using folic acid as the reference dose for estimation of the plasma kinetics and relative bioavailability of food folate.

Figure 2. Dose-normalized AUC of plasma $\left[{ }^{13} \mathrm{C}_{5}\right] 5$-methyltetrahydrofolate $(\mathrm{h} * \mathrm{nmol} / \mathrm{L})$ after single oral equimolar folate doses $(\approx 450 \mathrm{nmol}=200 \mu \mathrm{g})$ in the form of pharmaceutical preparation with $(6 S)-\left[{ }^{13} \mathrm{C}_{5}\right] 5$-methyltetrahydrofolate (MTHF, green) or $\left[{ }^{13} \mathrm{C}_{5}\right]$ folic acid (PGA, green) or as bread fortified with $(6 S)-\left[{ }^{13} \mathrm{C}_{5}\right] 5$-methyltetrahydrofolate (bread with MTHF, orange) or $\left[{ }^{13} \mathrm{C}_{5}\right]$ folic (bread with PGA, orange). * indicates an outlier. Data from $[46,86]$.

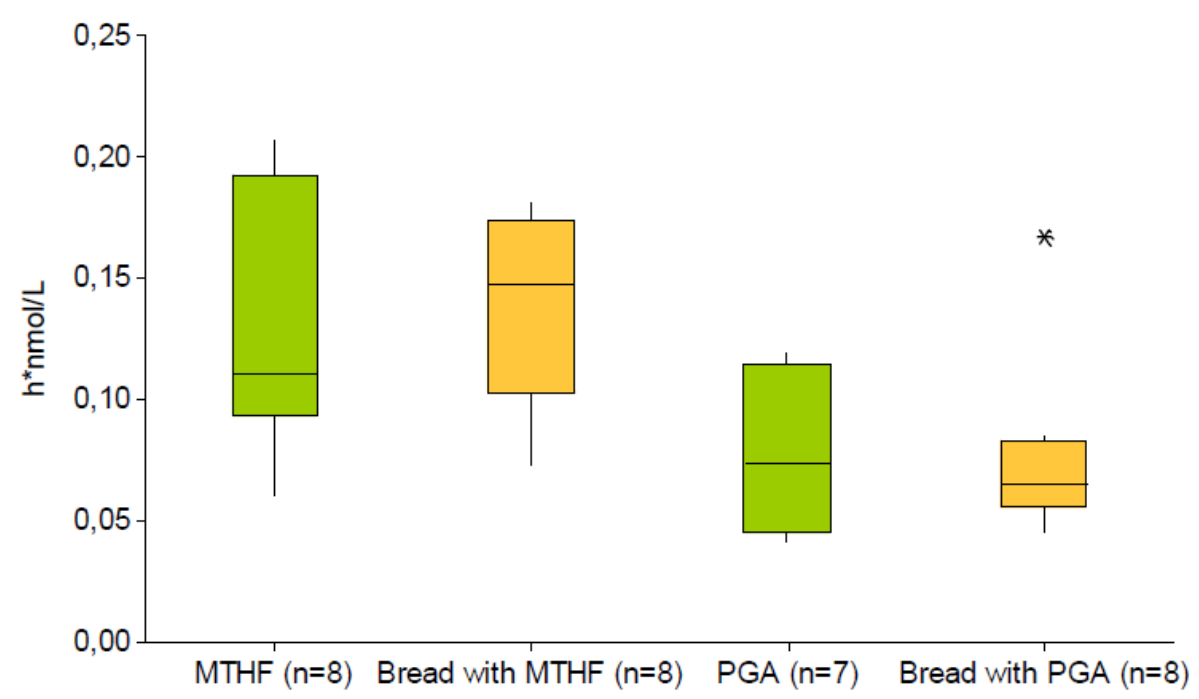

Even when the use of stable isotope-labeled folates (Table 3) offers the advantage of distinguishing between labeled folate from the dose and unlabeled endogenous folate $[17,19,42,46]$, no data on absorption of native food folates are obtained unless intrinsic labeling is used [18].

Current short-term folate bioavailability data are therefore limited to a few vegetables, fruits, cereal products, and fortified foods (Table 3 ) $[18,40,45,65,70,78]$ and have to be interpreted with caution. 


\section{Conclusions}

This summary of existing information shows that only limited folate bioavailability data are available for vegetables, fruits, cereal products and fortified foods. It also shows the difficulties in assessment. No safe conclusion can be drawn as to whether intervention with food folate results in improved folate status. Additionally, it is not possible to estimate the size of the required minimum intervention dose of food folate to achieve improvement of status, as the status parameters are affected to different extents.

However, the data highlight differences in the metabolic handling of folic acid and reduced folates in humans, as evidenced by differing acute post-absorptive plasma kinetics and different effects on fasting plasma folate concentrations after long-term intervention. It is still unclear whether these findings have implications for human health, and they need to be considered in recommendations regarding folic acid fortification of food. As it is not expected that the more expensive and less stable bioactive diastereoisomer (6S)-5-methyltetrahydrofolate $\left(\right.$ Metafolin ${ }^{\circledR}$ ) will be commonly used for fortification purposes, synthetic folic acid reference doses are appropriate for evaluation of the effectiveness of folic acid-fortified foods at population level.

An immediate consequence is our recommendation to revise the classical approach of using folic acid as the reference dose in estimating the plasma kinetics and relative bioavailability of food folate. The design of future studies on relative folate bioavailability faces the challenge of accounting for the bias from metabolic handling of folate compounds, and existing findings have to be interpreted with caution.

\section{References}

1. Katan, M.B.; Boekschoten, M.V.; Connor, W.E.; Mensink, R.P.; Seidell, J.; Vessby, B.; Willett, W. Which Are the Greatest Recent Discoveries and the Greatest Future Challenges in Nutrition? Eur. J. Clin. Nutr. 2009, 63, 2-10.

2. NNR. Nordic Nutrition Recommendations NNR 2004 Integrating Nutrition and Physical Activity; Nordic Council of Ministers: Stockholm, Sweden, 2005.

3. Dhonukshe-Rutten, R.A.M.; de Vries, J.H.M.; de Bree, A.; van der Put, N.; van Staveren, W.A.; de Groot, L. Dietary Intake and Status of Folate and Vitamin B12 and Their Association with Homocysteine and Cardiovascular Disease in European Populations. Eur. J. Clin. Nutr. 2009, 63, $18-30$.

4. de Bree, A.; van Dusseldorp, M.; Brouwer, I.A.; van het Hof, K.H.; Steegers-Theunissen, R.P.M. Review Folate Intake in Europe: Recommended, Actual and Desired Intake. Eur. J. Clin. Nutr. 1997, 51, 643-660.

5. Bergstrom, L. Nutrient Losses and Gains in the Preparation of Foods; National Food Administration: Sweden, Uppsala, 1994.

6. Mitchell, L.E.; Adzick, N.S.; Melchionne, J.; Pasquariello, P.S.; Sutton, L.N.; Whitehead, A.S. Spina bifida. Lancet 2004, 364, 1885-1895.

7. Gregory, J.F. Folate. In Food Chemistry; Fennema, O.R., Ed.; Marcel Dekker: New York, NY, USA, 1996; pp. 590-616. 
8. Mosley, B.S.; Cleves, M.A.; Siega-Riz, A.M.; Shaw, G.M.; Canfield, M.A.; Waller, D.K.; Werler, M.M.; Hobbs, C.A. Neural Tube Defects and Maternal Folate Intake among Pregnancies Conceived after Folic acid Fortification in the United States. Am. J. Epidemiol. 2009, 169, 9-17.

9. Yang, Q.; Botto, L.D.; Erickson, J.D.; Berry, R.J.; Sambell, C.; Johansen, H.; Friedman, J.M. Improvement in Stroke Mortality in Canada and the United States, 1990 to 2002. Circulation 2006, 113, 1335-1343.

10. Shirodaria, C.; Antoniades, C.; Lee, J.; Jackson, C.E.; Robson, M.D.; Francis, J.M.; Moat, S.J.; Ratnatunga, C.; Pillai, R.; Refsum, H.; Neubauer, S.; Channon, K.M. Global Improvement of Vascular Function and Redox State with Low-Dose Folic Acid. Circulation 2007, 115, 2262-2270.

11. Sanderson, P.; McNulty, H.; Mastroiacovo, P.; McDowell, I.F.W.; Melse-Boonstra, A.; Finglas, P.M.; Gregory, J.F. Folate Bioavailability: UK Food Standards Agency Workshop Report. Br. J. Nutr. 2003, 90, 473-479.

12. CDC. Water-Soluble Vitamins \& Related Biochemical Compounds; Centers for Disease Control and Prevention: Atlanta, GA, USA. Available online: http://www.cdc.gov/nutritionreport/ part_1.html (accessed on 13 July 2009).

13. Hannon-Fletcher, M.P.; Armstrong, N.C.; Scott, J.M.; Pentieva, K.; Bradbury, I.; Ward, M.; Strain, J.J.; Dunn, A.A.; Molloy, A.M.; Kerr, M.A.; McNulty, H. Determining Bioavailability of Food Folates in a Controlled Intervention Study. Am. J. Clin. Nutr. 2004, 80, 911-918.

14. Brouwer, I.A.; van Dusseldorp, M.; West, C.; Meyboom, S.; Thomas, C.M.G.; Duran, M.; van het Hof, K.H.; Eskes, T.K.A.B.; Hautvast, G.A.J.; Steegers-Theunissen, R.P.M. Dietary Folate from Vegetables and Citrus Fruit Decreases Plasma Homocysteine Concentrations in Humans in a Dietary Controlled trial. J. Nutr. 1999, 129, 1135-1139.

15. Gregory, J.F. The Bioavailability of Folate. In Folate in Health and Disease; Bailey, L.B., Ed.; Marcel Dekker: New York, NY, USA, 1995; pp. 195-235.

16. Melse-Boonstra, A.; Verhoef, P.; West, C. Quantifying Folate Bioavailability: A Critical Appraisal of Methods. Curr. Opin. Clin. Nutr. Metab. Care 2004, 7, 539-545.

17. Wright, A.J.A.; Finglas, P.M.; Dainty, J.R.; Hart, D.J.; Wolfe, C.A.; Southon, S.; Gregory, J.F. Single Oral Doses of C-13 Forms of Pteroylmonoglutamic Acid and 5-Formyltetrahydrofolic Acid Elicit Differences in Short-Term Kinetics of Labelled and Unlabelled Folates in Plasma: Potential Problems in Interpretation of Folate Bioavailability Studies. Br. J. Nutr. 2003, 90, 363-371.

18. Wright, A.J.A.; Finglas, P.M.; Dainty, J.R.; Wolfe, C.A.; Hart, D.J.; Wright, D.M.; Gregory, J.F. Differential Kinetic Behavior and Distribution for Pteroylglutamic Acid and Reduced Folates: A Revised Hypothesis of the Primary Site of PteGlu Metabolism in Humans. J. Nutr. 2005, 135, 619-623.

19. Wright, A.J.A.; King, M.J.; Wolfe, C.A.; Powers, H.J.; Finglas, P.M. Comparison of (6S)-5-methyltetrahydrofolic Acid v. Folic Acid as the Reference Folate in Longer-term Human Dietary Intervention Studies Assessing the Relative Bioavailability of Natural Food Folates: Comparative Changes in Folate Status Following a 16-week Placebo-controlled Study in Healthy Adults. Br. J. Nutr. 2010, 103, 724-729. 
20. Pfeiffer, C.M.; Fazili, Z.; Zhang, M. Folate Analytical Methodology. In Folate in Health and Disease, 2nd ed.; Bailey, L.B., Ed.; CRC Press: Boca Raton, FL, USA, 2010; pp. 517-574.

21. Finglas, P.M.; Scott, K.J.; Witthoft, C.M.; van den Berg, H.; de Froidmont-Gortz, I. The Certification of the Mass Fraction of Vitamins in Four Reference Materials: Wholemeal Flour (CRM 121), Milk powder (CRM 421), Lyophilised Mixed Vegetables (CRM 485) and Lyophilised Pig's Liver (CRM 487); EUR-Report 18320; Office for Official Publications, Commission of the European Union: Luxembourg, Luxembourg, 1999.

22. Vahteristo, L.T.; Finglas, P.M.; Witthoft, C.M.; Wigertz, K.; Seale, R.; De Froidmont-Gortz, I. Third EU MAT Intercomparison Study on Food Folate Analysis Using HPLC Procedures. Food Chem. 1996, 57, 109-111.

23. Caudill, M.A. Folate Bioavailability: Implications for Establishing Dietary Recommendations and Optimizing status. Am. J. Clin. Nutr. 2010, 91, 1455S-1460S.

24. Kim, Y.I. Folate and Colorectal Cancer: An Evidence-Based Critical Review. Mol. Nutr. Food Res. 2007, 51, 267-292.

25. Mason, J.B.; Dickstein, A.; Jacques, P.F.; Haggarty, P.; Selhub, J.; Dallal, G.; Rosenberg, I.H. A Temporal Association between Folic Acid Fortification and an Increase in Colorectal Cancer Rates May Be Illuminating Important Biological Principles: A Hypothesis. Cancer Epidemiol. Biomarkers Prev. 2007, 16, 1325-1329.

26. Smith, A.D.; Kim, Y.-I.; Refsum, H. Is Folic Acid Good for Everyone? Am. J. Clin. Nutr. 2008, 87, 517-533.

27. Halsted, C.H. Intestinal Absorption of Dietary Folates. In Folic Acid Metabolism in Health and Disease; Picciano, M.F., Gregory, J.F., Stokstad, E.L., Eds.; Wiley-Liss: New York, NY, USA, 1990; pp. 23-46.

28. Zhao, R.; Matherly, L.H.; Goldman, I.D. Membrane Transporters and Folate Homeostasis: Intestinal Absorption and Transport into Systemic Compartments and Tissues. Expert Rev. Mol. Med. 2009, 11, e4, doi:10.1017/S1462399409000969.

29. Aufreiter, S.; Gregory, J.F., III; Pfeiffer, C.M.; Fazili, Z.; Kim, Y.-I.; Marcon, N.; Kamalaporn, P.; Pencharz, P.B.; O'Connor, D.L. Folate is Absorbed across the Colon of Adults: Evidence from Cecal Infusion of 13C-Labeled [6S]-5-formyltetrahydrofolic Acid. Am. J. Clin. Nutr. 2009, 90, 116-123.

30. Camilo, E.; Zimmerman, J.; Mason, J.B.; Golner, B.; Russell, R.; Selhub, J.; Rosenberg, I.H. Folate Synthesized by Bacteria in the Human Upper Small Intestine is Assimilated by the Host. Gastroenterology 1996, 110, 991-998.

31. Asrar, F.M.; O'Connor, D.L. Bacterially Synthesized Folate and Supplemental Folic Acid Are Absorbed across the Large Intestine of Piglets. J. Nutr. Biochem. 2005, 16, 587-593.

32. Gregory, J.F.; Williamson, J.; Liao, J.F.; Bailey, L.B.; Toth, J.P. Kinetic Model of Folate Metabolism in Nonpregnant Women Consuming [H-2(2)]Folic Acid: Isotopic Labeling of Urinary Folate and the Catabolite Para-acetamidobenzoylglutamate Indicates Slow, Intake-Dependent, Turnover of Folate Pools. J. Nutr. 1998, 128, 1896-1906.

33. Herbert, V. Recommended Dietary Intakes (RDI) of Folate in Humans. Am. J. Clin. Nutr. 1987, $45,661-670$. 
34. Lin, Y.; Dueker, S.R.; Follett, J.R.; Fadel, J.G.; Arjomand, A.; Schneider, P.D.; Miller, J.W.; Green, R.; Buchholz, B.A.; Vogel, J.S.; Phair, R.D.; Clifford, A.J. Quantitation of in vivo Human Folate Metabolism. Am. J. Clin. Nutr. 2004, 80, 680-691.

35. Wagner, C. Biochemical Role of Folate in Cellular Metabolism. In Folate in Health and Disease; Bailey, L.B., Ed.; Clinical Nutrition in Health and Disease 1; Marcel Dekker: New York, NY, USA, 1995; pp. 23-42.

36. Tamura, T.; Picciano, M.F. Folate and Human Reproduction. Am. J. Clin. Nutr. 2006, 83, 993-1016.

37. Reed, M.C.; Nijhout, H.F.; Neuhouser, M.L.; Gregory, J.E.; Shane, B.; James, S.J.; Boynton, A.; Ulrich, C.M. A Mathematical Model Gives Insights into Nutritional and Genetic Aspects of Folate-Mediated One-Carbon Metabolism. J. Nutr. 2006, 136, 2653-2661.

38. Ohrvik, V. Folate Bioavailability. In-vitro Experiments and In-vivo Trials. Ph.D. Thesis, Swedish University of Agricultural Sciences, Uppsala, Sweden, 2009.

39. Gregory, J.F.; Caudill, M.A.; Opalko, F.J.; Bailey, L.B. Kinetics of Folate Turnover in Pregnant Women (Second Trimester) and Nonpregnant Controls during Folic Acid Supplementation: Stable-Isotopic Labeling of Plasma Folate, Urinary Folate and Folate Catabolites Shows Subtle Effects of Pregnancy on Turnover of Folate Pools. J. Nutr. 2001, 131, 1928-1937.

40. Witthoft, C.; Stralsjo, L.; Berglund, G.; Lundin, E. A Human Model to Determine Folate Bioavailability from Food: A Pilot Study for Evaluation. Scand. J. Nutr. 2003, 47, 6-18.

41. Pfeiffer, C.M.; Rogers, L.M.; Bailey, L.B.; Gregory, J.F. Absorption of Folate from Fortified Cereal-Grain Products and of Supplemental Folate Consumed with or Without Food Determined Using a Dual-Label Stable-Isotope Protocol. Am. J. Clin. Nutr. 1997, 66, 1388-1397.

42. Rogers, L.M.; Pfeiffer, C.M.; Bailey, L.B.; Gregory, J.F. A Dual-Label Stable-Isotopic Protocol Is Suitable for Determination of Folate Bioavailability in Humans: Evaluation of Urinary Excretion and Plasma Folate Kinetics of Intravenous and Oral Doses of [C-13(5)] and [H-2(2)]Folic Acid. J. Nutr. 1997, 127, 2321-2327.

43. Gregory, J.F.; Quinlivan, E.P. In vivo Kinetics of Folate Metabolism. Ann. Rev. Nutr. 2002, 22, 199-220.

44. Witthoft, C.M.; Arkbage, K.; Johansson, M.; Lundin, E.; Berglund, G.; Zhang, J.X.; Lennernas, H.; Dainty, J.R. Folate Absorption from Folate-Fortified and Processed Foods Using a Human Ileostomy Model. Br. J. Nutr. 2006, 95, 181-187.

45. Konings, E.J.M.; Troost, F.J.; Castenmiller, J.J.M.; Roomans, H.H.S.; van den Brandt, P.A.; Saris, W.H.M. Intestinal Absorption of Different Types of Folate in Healthy Subjects with an Ileostomy. Br. J. Nutr. 2002, 88, 235-242.

46. Ohrvik, V.E.; Buttner, B.E.; Rychlik, M.; Lundin, E.; Witthoft, C.M. Folate Bioavailability from Breads and a Meal Assessed with a Human Stable-Isotope Area under the Curve and Ileostomy Model. Am. J. Clin. Nutr. 2010, 92, 532-538.

47. Buttner, B.E.; Ohrvik, V.E.; Witthoft, C.M.; Rychlik, M. Quantification of Isotope-Labelled and Unlabelled Folates in Plasma, Ileostomy and Food Samples. Anal. Bioanal. Chem. 2011, 399, 429-439. 
48. Wilcken, B.; Bamforth, F.; Li, Z.; Zhu, H.; Ritvanen, A.; Redlund, M.; Stoll, C.; Alembik, Y.; Dott, B.; Czeizel, A.E.; et al. Geographical and Ethnic Variation of the 677C>T Allele of 5,10 Methylenetetrahydrofolate Reductase (MTHFR): Findings from over 7000 Newborns from 16 Areas World Wide. J. Med. Genet. 2003, 40, 619-625.

49. Rozen, R. Folate and Genetics. J. Food Sci. 2004, 69, S65-S67.

50. Gregory, J.F.; Quinlivan, E.P.; Davis, S.R. Integrating the Issues of Folate Bioavailability, Intake and Metabolism in the Era of Fortification. Trends Food Sci. Technol. 2005, 16, 229-240.

51. Morin, I.; Devlin, A.M.; Leclerc, D.; Sabbaghian, N.; Halsted, C.H.; Finnell, R.; Rozen, R. Evaluation of Genetic Variants in the Reduced Folate Carrier and in Glutamate Carboxypeptidase II for Spina Bifida Risk. Mol. Genet. Metab. 2003, 79, 197-200.

52. Tozer, T.; Rowland, M. Introduction to Pharmacokinetics and Pharmacodynamics; Lippincott Williams \& Wilkins: Baltimore County, MD, USA, 2006.

53. Gregory, J.F. Bioavailability of Folate. Eur. J. Clin. Nutr. 1997, 51, S54-S59.

54. Bouckeart, K.P.; Slimani, N.; Nicolas, G.; Vignat, J.; Wright, A.J.A.; Roe, M.; Witthoft, C.M.; Finglas, P.M. Critical Evaluation of Folate Data in European and International Databases: Recommendations for Standardization in International Nutritional Studies. Mol. Nutr. Food Res. 2011, 55, 166-180.

55. AACC International. Approved Methods of Analysis, 11th ed. Method 86-47.01. Total Folate in Cereal Products-Microbiological Assay Using Trienzyme Extraction; AACC International: St. Paul, MN, USA, 2000; doi:10.1094/AACCIntMethod-86-47.01.

56. DeVries, J.W.; Keagy, P.M.; Hudson, C.A.; Rader, J.I. AACC Collaborative Study of a Method for Determining Total Folate in Cereal Products-Microbiological Assay Using Trienzyme Extraction (AACC method 86-47). Cereal Food World 2001, 46, 216-219.

57. Cho, S.; Choi, Y.; Lee, J.; Eitenmiller, R.R. Optimization of Enzyme Extractions for Total Folate in Cereals Using Response Surface Methodology. J. Agric. Food Chem. 2010, 58, 10781-10786.

58. Riddell, L.J.; Chisholm, A.; Williams, S.; Mann, J.I. Dietary Strategies for Lowering Homocysteine Concentrations. Am. J. Clin. Nutr. 2000, 71, 1448-1454.

59. Ohrvik, V.E.; Olsson, J.C.; Sundberg, B.E.; Witthoft, C.M. Effect of 2 pieces of nutritional advice on folate status in Swedish women: A randomized controlled trial. Am. J. Clin. Nutr. 2009, 89, 1053-1058.

60. Vahteristo, L.; Kariluoto, S.; Barlund, S.; Karkkainen, M.; Lamberg-Allardt, C.; Salovaara, H.; Piironen, V. Functionality of Endogenous Folates from Rye and Orange Juice Using Human in vivo Model. Eur. J. Nutr. 2002, 41, 271-278.

61. Winkels, R.M.; Brouwer, I.A.; Siebelink, E.; Katan, M.B.; Verhoef, P. Bioavailability of Food Folates is $80 \%$ of that of Folic Acid. Am. J. Clin. Nutr. 2007, 85, 465-473.

62. Venn, B.J.; Mann, J.I.; Williams, S.M.; Riddell, L.J.; Chisholm, A.; Harper, M.J.; Aitken, W. Dietary Counseling to Increase Natural Folate Intake: A Randomized, Placebo-Controlled Trial in Free-living Subjects to Assess Effects on Serum Folate and Plasma Total Homocysteine. Am. J. Clin. Nutr. 2002, 76, 758-765.

63. Fenech, M.; Noakes, M.; Clifton, P.; Topping, D. Aleurone Flour Increases Red-Cell Folate and Lowers Plasma Homocyst(E)Ine Substantially in Man. Br. J. Nutr. 2005, 93, 353-360. 
64. Pentieva, K.; McNulty, H.; Reichert, R.; Ward, M.; Strain, J.J.; McKillop, D.J.; McPartlin, J.M.; Connolly, E.; Molloy, A.; Kramer, K.; Scott, J.M. The Short-term Bioavailabilities of [6S]-5-Methyltetrahydrofolate and Folic Acid Are Equivalent in Men. J. Nutr. 2004, 134, $580-585$.

65. Fenech, M.; Noakes, M.; Clifton, P.; Topping, D. Aleurone Flour is a Rich Source of Bioavailable Folate in Humans. J. Nutr. 1999, 129, 1114-1119.

66. Cuskelly, G.J.; McNulty, H.; Scott, J.M. Effect of Increasing Dietary Folate on Red-Cell Folate: Implications for Prevention of Neural Tube Defects. Lancet 1996, 347, 657-659.

67. Broekmans, W.M.R.; Klopping-Ketelaars, I.A.A.; Schuurman, C.R.W.C.; Verhagen, H.; van den Berg, H.; Kok, F.J.; van Poppel, G. Fruits and Vegetables Increase Plasma Carotenoids and Vitamins and Decrease Homocysteine in Humans. J. Nutr. 2000, 130, 1578-1583.

68. Bogers, R.P.; Dagnelie, P.C.; Bast, A.; van Leeuwen, M.; van Klaveren, J.D.; van den Brandt, P.A. Effect of Increased Vegetable and Fruit Consumption on Plasma Folate and Homocysteine Concentrations. Nutrition 2007, 23, 97-102.

69. Ashfield-Watt, P.A.L.; Whiting, J.M.; Clark, Z.E.; Moat, S.J.; Newcombe, R.G.; Burr, M.L.; McDowell, I.F.W. A Comparison of the Effect of Advice to Eat Either "5-A-Day" Fruit and Vegetables or Folic Acid-Fortified Foods on Plasma Folate and Homocysteine. Eur. J. Clin. Nutr. 2003, 57, 316-323.

70. Prinz-Langenohl, R.; Bronstrup, A.; Thorand, B.; Hages, M.; Pietrzik, K. Availability of Food Folate in Humans. J. Nutr. 1999, 129, 913-916.

71. Enghardt-Barbieri, H.; Lindvall, C. Swedish Nutrition Recommendations Objectified (SNO)_Basis for General Advice on Food Consumption for Healthy Adults; National Food Administration: Sweden, Uppsala, 2005.

72. Summers, C.M.; Mitchell, L.E.; Stanislawska-Sachadyn, A.; Baido, S.F.; Blair, I.A.; Von Feldt, J.M.; Whitehead, A.S. Genetic and Lifestyle Variables Associated with Homocysteine Concentrations and the Distribution of Folates Derivatives in Healthy Premenopausal Women. Birth Defects Res. A 2010, 88, 679-688.

73. McKinley, M.C.; Strain, J.J.; McPartlin, J.; Scott, J.M.; McNulty, H. Plasma Homocysteine Is Not Subject to Seasonal Variation. Clin. Chem. 2001, 47, 1430-1436.

74. Clarke, R.; Woodhouse, P.; Ulvik, A.; Frost, C.; Sherliker, P.; Refsum, H.; Ueland, P.M.; Khaw, K.-T. Variability and determinants of Total Homocysteine Concentrations in Plasma in an Elderly Population. Clin. Chem. 1998, 44, 102-107.

75. Garg, U.C.; Zheng, Z.-J.; Folsom, A.R.; Moyer, Y.S.; Tsai, M.Y.; McGovern, P.; Eckfeldt, J.H. Short-Term and Long-Term Variability of Plasma Homocysteine Measurement. Clin. Chem. 1997, 43, 141-145.

76. Antoniades, C.; Shirodaria, C.; Leeson, P.; Baarholm, O.A.; Van-Assche, T.; Stefanadis, C.; Refsum, H.; Channon, K.M. MTHFR 677 C>T Polymorphism Reveals Functional Importance for Methyltetrahydrofolate, Not Homocysteine, in Regulation of Vascular Redox State and Endothelial Function in Human Atherosclerosis. Circulation 2009, 119, 2507-2515.

77. Tamura, T.; Stokstad, E.L. Availability of Food Folate in Man. Br. J. Haematol. 1973, 25, $513-532$. 
78. Achon, M.; Arrate, A.; Alonso-Aperte, E.; Varela-Moreiras, G. Plasma Folate Concentrations after a Single Dose Ingestion of Whole and Skimmed Folic Acid Fortified Milks in Healthy Subjects. Eur. J. Nutr. 2011, 50, 119-125.

79. Colman, N.; Green, R.; Metz, J. Prevention of Folate Deficiency by Food Fortification. II. Absorption of Folic Acid from Fortified Staple Foods. Am. J. Clin. Nutr. 1975, 28, 459-464.

80. Finglas, P.M.; Witthoft, C.M.; Vahteristo, L.; Wright, A.J.A.; Southon, S.; Mellon, F.A.; Ridge, B.; Maunder, P. Use of an Oral/Intravenous Dual-Label Stable-Isotope Protocol to Determine Folic Acid Bioavailability from Fortified Cereal Grain Foods in Women. J. Nutr. 2002, 132, 936-939.

81. Wei, M.M.; Bailey, L.B.; Toth, J.P.; Gregory, J.F. Bioavailability for Humans of Deuterium-Labeled Monoglutamyl and Polyglutamyl Folates Is Affected by Selected Foods. J. Nutr. 1996, 126, 3100-3108.

82. Gregory, J.F.; Bhandari, S.D.; Bailey, L.B.; Toth, J.P.; Baumgartner, T.G.; Cerda, J.J. Relative Bioavailability of Deuterium-Labeled Monoglutamyl and Hexaglutamyl Folates in Human-Subjects. Am. J. Clin. Nutr. 1991, 53, 736-740.

83. Buchholz, B.A.; Arjomand, A.; Dueker, S.R.; Schneider, P.D.; Clifford, A.J.; Vogel, J.S. Intrinsic Erythrocyte Labeling and Attomole Pharmacokinetic Tracing of 14C-Labeled Folic Acid with Accelerator Mass Spectrometry. Anal. Biochem. 1999, 269, 348-352.

84. Wigertz, K. Milk Folates - Characterisation and Availability. Ph.D. Thesis, Lund University, Lund, Sweden, 1997.

85. Ashokkumar, B.; Mohammed, Z.M.; Vaziri, N.D.; Said, H.M. Effect of Folate Oversupplementation on Folate Uptake by Human Intestinal and Renal Epithelial Cells. Am. J. Clin. Nutr. 2007, 86, 159-166.

86. Ohrvik, V.E.; Buttner, B.E.; Rychlik, M.; Lundin, E.; Witthoft, C.M. The Bioavailability of Folic Acid and Reduced Folate Bioavailability from Foods and Pharmaceutical Preparations Assessed With a Human Stable-Isotope Area under the Curve and Ileostomy Model. 2011, unpublished work.

(C) 2011 by the authors; licensee MDPI, Basel, Switzerland. This article is an open access article distributed under the terms and conditions of the Creative Commons Attribution license (http://creativecommons.org/licenses/by/3.0/). 